Arch. Tierz., Dummerstorf 44 (2001) 1, 5-13

Department of Livestock Sciences. University of Agricultural Sciences Vienna, Austria

ROSWITHA BAUMUNG, JOHANN SOLLKNER, ERWIN GIERZINGER and

ALFONS WILLAM

\title{
Ecological total merit index for an Austrian dual purpose cattle breed
}

\begin{abstract}
Summary
Organic farming plays a considerable role in Austrian agriculture. Therefore it seems to be worthwhile to make suggestions about a more ecological breeding goal for cattle breeds. Because of the fact that Simmental is the most frequent dual purpose cattle breed in Austria, this breed is chosen to show the impact of selection under an "ecological" total merit index. With model calculations the effect on selection response in milk production, beef production and functional traits under selection with the current economic total merit index and more ecological index variants, e.g. with higher economic values for fitness and functional traits, is shown. As a basis for future decisions the efficiency of more or less ecological indices is compared. The results indicate that an increase of the current economic values of functional traits of about 50 percent does not present a great risk, expected selection responses for milk production traits are still high.
\end{abstract} Key Words: total merit index, functional and fitness traits, cattle breeding, ecological breeding goals, genetic and
economic evaluation

\section{Zusammenfassung}

Titel der Arbeit: Ökologischer Gesamtzuchtwerı für das Fleckvieh in Österreich

In Ósterreichs Landwirtschaft spielt die ökologische Wirtschaftsweise eine bedeutende Rolle, daher scheinen Öberlegungen zu einem stärker ökologisch orientierten Zuchtziel in der Rinderzucht durchaus angebracht. Die Auswirkungen einer Selektion auf einen „okologischen" Gesamtzuchtwert wird anhand der Rasse: Fleckvieh, welche in Österreich die stärkste Verbreitung hat, gezeigt. Mittels Modellkalkulationen wird der zu erwartende Zuchtfortschritt bei Milchleistungs-, Fleischleistungs- und Fitnessmerkmalen bei Selektion nach dem derzeitigen ökonomischen Gesamtzuchtwert mit mehr oder weniger ökologischen Index-Varianten, d.h. mit stärkerer Gewichtung der Fitnessmerkmale, verglichen. Als Grundlage fur zuklunftige Entscheidungen wird die ökonomische Effizienz der verschiedenen Indices verglichen. Die Ergebnisse lassen darauf schließen, dass eine Erhöhung der wirtschaftlichen Gewichte für Fitnessmerkmale im aktuellen osterreichischen Gesamtzuchtwert um etwa 50 Prozent kein großes Risiko birgt. Der Zuchtfortschritt bei Milch- und Fleischleistungsmerkmalen bleibt relativ hoch.

Schlüsselwörter: Gesamtzuchtwert, funktionale Merkmale und Fitnessmerkmale. Rinderzucht, okologische Zuchtziele, genetische und ökonomische Beurteilung

1. Introduction

In breeding objectives traits should be included according to their economic importance. MIESENBERGER (1997) estimated such economic weights for production traits and functional traits using a herd model for Austrian cattle breeds. The economic weights of several functional traits (e.g. longevity) turned out to be high (MIESENBERGER et al., 1998). An improvement in one of those traits increases the efficiency of an animal not by higher output of products but mainly by reduced input of costs (GROEN et al., 1996; MIESENBERGER, 1997). Some authors (DEMPFLE, 
1992; GROEN et al.,1996) point out that in addition to economic reasons for including functional traits in the breeding programmes there are several other reasons, for example ethical reasons and consumer concern, which become more and more important. For this reason and because of the fact that organic farming plays a considerable role in Austrian agriculture, it seems worthwhile to make suggestions about a more ecological breeding goal for cattle breeds.

In the following "ecology" is defined in a broad sense. The ecological system includes not only the manifold interactions between organisms and their environment but also physiological relationships within the organism itself (CAPRA, 1997). Therefore an ecological total merit index has to deal with characters which are indicators for the inner balance of an organism like health and fertility traits.

This study shows different possibilities how to create a more ecological orientated total merit index for the dual purpose Simmental population, which is the most frequent cattle breed in Austria. Further, the effect on the expected selection response in milk production, beef production and functional traits under selection with the current economic total merit index and more ecological index variants, e.g. with higher economic weights of the functional traits, is shown. The efficiency of different indices is compared to get a basis for future decisions.

2. Material and methods

To estimate the economic weights and calculate a total merit index a herd model and methods described by MIESENBERGER et al. (1998) and MIESENBERGER (1997) were used.

\subsection{Estimation of the economic weights}

A herd including milk production, bull fattening and heifer rearing was simulated in a steady state over an infinite planning term. A computer program developed by AMER et al. (1994), which was adapted by MIESENBERGER et al. (1998) was used to compute the economic weights for the various traits by calculating herd profit per year before and after a genetic change. The resulting difference in herd profit was divided by the number of cows per herd. All costs were treated as variable, For a more detailed description see MIESENBERGER et al. (1998).

All economic weights presented in this study were calculated under the assumption of a quota on fat and protein yield. A reference situation was defined with respect to the Simmental population in Austria. The average milk yield per cow place and year was $5321 \mathrm{~kg}$ milk, $223 \mathrm{~kg}$ fat and $180 \mathrm{~kg}$ protein. The age structure of the herd modelled approximated the situation in the present Austrian Simmental population (see MIESENBERGER et al., 1998). Prices and costs in the basis situation were average prices in Austria in 1996. Some of the prices considered are given in Table 1 (scenario I).

\subsection{Modelling of the breeding programme}

The program ZPLAN (KARRAS et al., 1994) was used to describe the Austrian Simmental breeding programme. For predicting the annual genetic gain a pure deter- 
ministic approach is employed. One round of selection is considered with its impact on a given time horizon with specific discount rates. All selection groups in the whole population are to be defined, each with a specific selection intensity and with particular sources of information (type and number of relatives) for index selection. The ZPLAN method applies the gene flow method described by MC CLINTOCK and CUNNINGHAM (1974), HILL (1974) and ELSEN and MOCQUOT (1974) to calculate a number of criteria such as annual monetary genetic gain for the aggregate genotype, annual genetic gain for single traits, discounted return and discounted profit over the given investment period. These criteria allow the evaluation of the genetic and economic efficiency of breeding programmes. Using this program different genetic improvement schemes have been evaluated by GRASER et al. (1994), RIEDL (1996), MÜELLER (1995), KOMINAKIS et al, (1997), WÜNSCH et al, (1999) and SÖLKNER et al. (2000). In the following some of the most important imput parameters for the Austrian Simmental population are given. For a more detailed description see SÖLKNER et al. (2000).

Total population size

Proportion of recorded cows

Proportion of AI

0.35

No. of young bulls tested per year

0.88

No. of proven bulls selected per year

130

No. of selected bull dams per year (elite-matings)

16

Use of young bulls (years)

Use of proven bulls (years)

2,000

Use of natural service bulls (years)

0.4

2.0

Use of bull dams (years)

2.2

Use of dams (years)

3.0

3.8

Mean generation interval in years (all selection groups) $\quad 5.65$

Milk recording costs per cow (EURO) 47

Investment period (years)

\subsection{Development of an ecological total merit index}

There are several possibilities to alter an index in direction of a more ecological breeding goal. Different traits can be included in the total merit index and the economic weights of these traits can be changed. Both possibilities are discussed subsequently.

\subsubsection{Choice of traits}

Which traits should be taken into account in an ecological total merit index has to be clarified when the breeding goal is defined. In case of a meaningful ecological breeding goal one supposition should be to include traits for health and fertility into the index. MIESENBERGER et al. (1998) showed that functional traits should be included in the aggregate genotype also from an economic point of view. Selection for such a total merit index will result in a higher economic efficiency than selection for production traits only (see also SÖLKNER et al, 2000). In the total merit index in 
Austria the following traits are incorporated: fat and protein yields, daily gain, dressing percentage, EUROP grading score, longevity, persistency, paternal and maternal fertility, paternal and maternal calving ease, paternal and maternal stillbirth and somatic cell count. Fat and protein yields are combined in the subindex "milk value", daily gain, carcass percentage and EUROP grading score give the "beef value" and the combination of all other traits, the functional traits, results in the "fitness value". Because of the consideration of the functional traits the current economic total merit index in Austria can be judged positively with regard to an ecological orientated choice of traits.

The scenarios considered subsequently include only traits currently used in the total merit index in Austria. Feed intake capacity and efficiency of feed utilisation are not included in these indices although improvement of such traits may lead to a reduction of environmental costs, e.g. due to less nitrogen secretion per unit of product. GROEN et al. (1996) point out that feed intake is a very complex trait, which can not be treated separately but should always be considered in relation to milk production and body weight. The question whether a reduction or an increase in (residual) feed intake (capacity) should be considered, is not solved yet.

\subsubsection{Relative economic weight of the traits}

The calculation of economic weights with the herd model requires assumptions with regard to the costs of input. Under ecological aspects costs for the environmental pollution and consumption of fossil energy have to be taken into account. It is assumed that the consideration of such external costs leads to higher prices for feedstuffs such as concentrate and corn silage. From a social standpoint the value of agricultural products (milk, beef) has to be higher. Therefore economic weights were calculated under different scenarios with regard to costs and returns (Table 1). The resulting weights were used to construct 4 different selection indices. The following scenarios were assumed:

Scenario I: Costs and returns used by MIESENBERGER et al. (1998) were assumed. The economic weights correspond to those assumed for the current total merit index in Austria.

Scenario II: Costs of $1 \mathrm{~kg}$ of dry matter of concentrate (barley and soya) were 50 percent higher than under scenario I (see Table 1)

Scenario III: The same assumptions as in scenario II, but the costs of corn silage are increased additionally. One energy unit (MJ NEL) of corn silage is as expensive as one energy unit of grass silage (Table 1)

Scenario IV: The same costs as in scenario III were assumed, but no corn silage was used in cattle feeding.

To take social aspects into consideration returns of agricultural products were increased in scenario III and IV (see Table 1). The milk price per $\mathrm{kg}$ was increased by 0.015 EUR, beef price per $\mathrm{kg}$ carcass weight by 0.360 EUR. These are typical differences between prices paid to organic farmers in comparison to conventional products. 
Table I

Some returns and costs in the 6 different index scenarios in Euro (Eriose und Kosten unter 6 unterschiedlichen Indexszenarien in Euro)

\begin{tabular}{|c|c|c|c|c|}
\hline & \multicolumn{4}{|c|}{ Scenario } \\
\hline & I, V, VI & II & III & IV \\
\hline \multicolumn{5}{|l|}{ Returns per kg } \\
\hline Milk carrier & 0.04 & 0.04 & 0.05 & 0.05 \\
\hline Milk fat & 3.37 & 3.37 & 3.37 & 3.37 \\
\hline Milk protein & 4.20 & 4.20 & 4.20 & 4.20 \\
\hline Buil (carcass weight) & 3.02 & 3.02 & 3,38 & 3.38 \\
\hline \multicolumn{5}{|l|}{ Costs per kg drymatter } \\
\hline Barley & 0.18 & 0.27 & 0.27 & 0.27 \\
\hline Soya & 0.28 & 0.42 & 0.42 & 0.42 \\
\hline Grass silage & $0 ; 12$ & 0.12 & 0.12 & 0.12 \\
\hline Corn silage & 0.11 & 0.11 & 0.13 & - \\
\hline
\end{tabular}

In deriving economic weights for functional traits, especially reproductive and health traits related to animal welfare, it is important to consider public opinion and consumer attitude towards animal production (GROEN et al., 1996). To provide some indication of the effects of selection according to a total merit index where ethical aspects with regard to animal welfare are taken into consideration, two further index variants were investigated. The weights of the traits, which constitute the subindex "Fitness value" in the current Austrian total merit index were increased arbitrarily,

Scenario V: Economic weights for all traits of the "Fitness value" 50 per cent higher than in scenario I

Scenario VI: Economic weights for all traits of the "Fitness value" 100 per cent higher than in scenario I

Table 2 gives an overview of the economic weights of the traits included in the 6 indices.

Table 2

Genetic standard deviation $\left(\mathrm{s}_{\mathrm{A}}\right)$ and economic weights per genetic standard deviation for the 6 scenarios (genetische Standardabweichungen $\left(s_{\Lambda}\right)$ und wirtschaftliche Gewichte pro genetischer Standardabweichung für die 6 Szenarien)

\begin{tabular}{|c|c|c|c|c|c|c|c|c|}
\hline \multirow[t]{2}{*}{ trait } & \multirow[t]{2}{*}{$\mathrm{s}_{\mathrm{A}}$} & \multirow[t]{2}{*}{ unit } & \multicolumn{6}{|c|}{ economic weight in scenario } \\
\hline & & & 1 & II & III & IV & V & VI \\
\hline Fat yield & 15.60 & $\mathrm{~kg}$ & 26.05 & 20.41 & 22.67 & 21.54 & 26.05 & 26.05 \\
\hline Protein yield & 10.50 & $\mathrm{~kg}$ & 27.51 & 24.42 & 26.71 & 28.23 & 27.51 & 27.51 \\
\hline Daily gain & 47.00 & $\mathrm{~g}$ & 11.28 & 9.22 & 9.56 & 9.56 & 11.28 & 11.28 \\
\hline Dressing percentage & 1.14 & $\%$ & 11.26 & 11,26 & 11.26 & 11.26 & 11.26 & 11.26 \\
\hline EUROP grading score & 0.25 & class & 4.22 & 4.07 & 4.07 & 4.07 & 4.22 & 4.22 \\
\hline Longevity & 180 & day & 21.60 & 22,76 & 21.60 & 21.60 & 32.40 & 43.20 \\
\hline Persistency & 1 & $s_{\lambda}$ & 2.91 & 4.87 & 3.92 & 2.54 & 4.37 & 5.82 \\
\hline Fertility paternal & 5 & $\%$ & 7.25 & 6.54 & 6,54 & 6.90 & 10,88 & 14.50 \\
\hline Fertility maternal & 5 & $\%$ & 7.25 & 6.54 & 6,54 & 6.90 & 10.88 & 14.50 \\
\hline Calving ease paternal & 0.22 & class & 1.71 & 1.71 & 1.71 & 1.71 & 2.57 & 3.42 \\
\hline Calving ease maternal & 0.22 & class & 1.71 & 1.71 & 1.71 & 1.71 & 2.57 & 3.42 \\
\hline Stillbirth paternal & 2.5 & $\%$ & 4.00 & 2.91 & 3.82 & 3.63 & 6.00 & 8,00 \\
\hline Stillbirth maternal & 2.5 & $\%$ & 4.00 & 2.91 & 3.82 & 3.63 & 6.00 & 8,00 \\
\hline Somatic cell count & 1 & $\mathrm{~s}_{\mathrm{A}}$ & 14.53 & 14.53 & 14.53 & 14.53 & 21.80 & 29.06 \\
\hline
\end{tabular}


3.

3.1 Relative economic importance of subindices

Table 3 shows that the consideration of external costs leads only to a marginal shift of the relative importance of the three subindices "Milk Value", "Beef Value" and "Fitness Value", favouring the "Fitness value" (scenario II to IV in comparison with scenario I). The reason for this shift was a higher economic weight of the functional trait persistency under scenario II and III. The weight of persistency increases due to higher concentrate costs. This confirms the results of MIESENBERGER (1997), who showed an increase of the economic weight of persistency under increasing costs for concentrate. Generally higher feeding costs lead to lower economic weights of functional traits, where an improvement is coupled with increased feedstuff consumption.

\section{Table 3}

Relative economic importance of the 3 subindices "Milk Value", "Beef Value" and "Fitness Value" under the 6 scenarios (Relative wirtschaftliche Bedeutung der 3 Subindizes "Milchwert", "Fleischwert" und "Fitnesswert" unter den 6 Szenarien)

\begin{tabular}{|c|c|c|c|}
\hline Scenario & Milk Value & Beef Value & Fitness Value \\
\hline 1 & 37 & 18 & 45 \\
\hline ii & 32 & 19 & 49 \\
\hline III & 36 & 18 & 46 \\
\hline IV & 36. & 18 & 46 \\
\hline $\mathrm{V}$ & 30 & 15 & 55 \\
\hline VI & 25 & 13 & 62 \\
\hline
\end{tabular}

The arbitrary increase of the weights of the functional traits caused a stronger shift of the relative importance of the subindices towards the traits combined in the "Fitness value" (scenario V and VI compared to scenario I).

\subsection{Expected selection response under selection with different total merit} indices.

The results given in this chapter are intended to provide some indication of the effects of selection according to the 6 scenarios presented in this paper. When interpreting the expected selection responses one should be aware of the assumptions. Table 4 contains the selection response per year in genetic standard deviations for each trait under the 6 different scenarios. Selection with the current total selection index in Austria (scenario I) lead to an improvement of all considered traits except four functional traits. Small negative responses were observed for paternal and maternal fertility, paternal calving ease and paternal stillbirth. Selection with indices where external costs were considered (scenario II, III and IV) yielded similar results though there is less deterioration in the functional traits mentioned above. The picture changed under scenario $\mathrm{V}$ and VI where a higher economic weight is put on the functional traits, but even under scenario VI a small negative response of paternal calving ease and paternal stillbirth was observed. The application of the indices under scenario V and VI allowed no improvement of the trait dressing percentage. Table 4 also illustrates that with higher weights for the functional traits the selection response for traits combined in the "milk value" decreased by 19 and 38 percent, respectively. 
Table 4

Natural selection response per year in genetic standard deviations under the 6 scenarios (Naturaler Zuchtfortschritt pro Jahr in genetischen Standardabweichungen unter den 6 Szenarien)

\begin{tabular}{lrrrrrr}
\hline trait & \multicolumn{7}{c}{ natural selection response under scenario } \\
& I & II & III & IV & V & VI \\
\hline Fat yield & 0.180 & $0.16 \mathrm{I}$ & 0.174 & 0.174 & 0.146 & 0.111 \\
Protein yield & 0.179 & 0.162 & 0.174 & 0.176 & 0.145 & 0.111 \\
Daily gain & 0.083 & 0.078 & 0.078 & 0.079 & 0.076 & 0.066 \\
Dressing percentage & 0.003 & 0.011 & 0.007 & 0.007 & -0.004 & -0.009 \\
EUROP grading score & 0.017 & 0.021 & 0.019 & 0.019 & 0.010 & 0.004 \\
Longevity & 0.051 & 0.068 & 0.057 & 0.056 & 0.088 & 0.114 \\
Persistency & 0.046 & 0.061 & 0.052 & 0.048 & 0.065 & 0.077 \\
Fertility paternal & -0.009 & -0.004 & -0.007 & -0.008 & 0.002 & 0.010 \\
Fertility maternal & -0.023 & -0.015 & -0.020 & -0.021 & -0.001 & 0.014 \\
Calving ease paternal & -0.031 & -0.030 & -0.030 & -0.031 & -0.027 & -0.022 \\
Calving ease maternaI & 0.069 & 0.069 & 0.070 & 0.069 & 0.079 & 0.084 \\
Stillbirth paternal & -0.008 & -0.009 & -0.008 & -0.008 & -0.007 & -0.005 \\
Stillbirth maternal & 0.039 & 0.040 & 0.041 & 0.040 & 0.052 & 0.061 \\
Somatic cell count & 0.001 & 0.015 & 0.007 & 0.006 & 0.033 & 0.058 \\
& & & & & & \\
\hline
\end{tabular}

\subsection{Economic efficiency of the different total merit indices}

The economic efficiency expresses the robustness and efficiency of a certain set of economic weights used in a total merit index with regard to the monetary total selection response (GIBSON, 1995). The economic efficiency is calculated by multiplying the natural selection response of the single traits under selection with the "used" total merit index with the corresponding economic weights of the "true" total merit index. These products are summed up and divided by the expected monetary total selection response with the "true" total merit index. Table 5 shows the proportion of the monetary total selection response, which can be achieved by use of an index with the economic weights of the index for the scenario in the respective line under the assumption that the weights of the index in the respective column are "true".

Table 5

Economic efficiency with regard to the monetary total selection response per year of the used index scenario relative to the "true" index scenario (bold) in the respective line (Okonomische Effizienz bezogen auf den jährlichen monetären Gesamtzuchtfortschritt des verwendeten Index relativ zum "wahren" Index (fett) in der jeweiligen Zeile)

\begin{tabular}{|c|c|c|c|c|c|c|}
\hline & 1 & II & III & IV & $\mathrm{V}$ & VI \\
\hline 1 & 1.00 & 1.00 & 1.00 & 1.00 & 0.97 & 0.89 \\
\hline II & 0.98 & 1.00 & 0.99 & 0.99 & 0.98 & 0.93 \\
\hline III & 1.00 & 1.00 & 1.00 & 1.00 & 0.98 & 0.91 \\
\hline IV & 1.00 & 1.00 & 1.00 & 1.00 & 0.98 & 0.91 \\
\hline V & 0.97 & 1.00 & 0.98 & 0.97 & 1.00 & 0.98 \\
\hline VI & 0.89 & 0.95 & 0.92 & 0.91 & 0.98 & 1.00 \\
\hline
\end{tabular}

In the first line of Table 5 the economic weights used in the current Austrian total selection index are assumed to be "true". From an economic point of view the indices under scenario II to IV were of the same value. A selection index with $50 \%$ higher economic weights (scenario V) lead to marginally reduced economic efficiency ( $3 \%$ less efficiency). Doubling the economic weights of functional traits in the selection 
index under scenario I reduced the efficiency by $11 \%$. Irrespective of the assumed "true" scenario the economic efficiency of the index under scenario V was about 97 to $98 \%$.

\section{Conclusions}

The derivation of economic traits with a herd model with and without consideration of external costs leads to almost identical economic weights for the single traits. Selection responses under selection with indices based on such economic weights did not differ very much. Recording of external costs and a subsequent calculation of economic weights is not the most effective way to construct a more ecological total merit index, because the economic weights turned out to be relative insensitive to the assumed external costs.

Interpreting the calculated expected selection responses for the single traits one should be aware of the fact that the assumed correlations between the traits play a considerable role. Under the assumed genetic and phenotypic correlations it could be shown that increasing the economic weights of functional traits directly is a reasonable possibility to take some ecological values into account. This way to alter economic weights pays regard to external costs indirectly. SUNDRUM (1997) showed that increasing the average age of cows from 5.1 to 5.6 years was more effective with regard to methane emission than increasing the mean milk performance by $1.000 \mathrm{~kg}$ per year.

From an economic point of view there is no great risk in increasing the economic weights of functional traits by $50 \%$. The economic efficiency of such a selection is reduced marginally compared to a selection using an index with currently used economic weights of the single traits. The lower selection response of milk traits is nearly compensated by the higher response of functional traits. Nevertheless, due to the high subjective value of the milk traits in practice such an ecological total merit index may be at a competetive disadvantage beyond economic reasons.

\section{References}

AMER, P.R.; KAUFMANN, A.; KÜNZI, N.:

Implications for farmers and political institutions from a Swiss cattle farm model. $3^{\text {rd }}$ International Livestock Farming System Symposium, Aberdeen, September, 1-2, 1994

CAPRA, F:

The Web of Life: A New Understanding of Living Systems. Doubleday, 1997

DEMPFLE, L.:

Berücksichtigung von Fruchtbarkeit und Eutergesundheit in der Rinderzlichtung, Zuichtungskunde 64 (1992), 447-457

ELSEN, J.M.; MOCQUOT, J.C.:

Méthode de prévision de l'évolution du niveau génétique d'une population soumise à une opération de sélection et dont les générations se chevauchent. INRA Bull. Tech. Dépt. Génét. Anim. 17 (1974), 3054

GIBSON, J.P,:

An introduction to the design and economics of animal breeding strategies. Eigenverlag University of Guelph. Summer course, Prague, Sep. 1995

GRASER, H.-U;; NITTER, G.; BARWICK, S.A.:

Evaluation of advanced industry breeding schemes for Australian Beef Cattle. II. Selection on combinations of growth, reproduction and carcass criteria. Australian Journal of Agricultural Research 45 (1994), 1641-1656 
GROEN, A.F.; STEINE, T.; COLLEAU, J.J.; PEDERSEN, J.; PRIBYL, J.; REINSCH, N.:

Economic values in dairy cattle breeding, with special reference to functional traits. Report of an HILL, W.G.: EAAP-working group. EAAP-Meeting in Lillehammer. 1996

Prediction and evaluation of response to selection with overlapping generations. Anim. Prod., 18 (1974), 117-139

KARRAS, K.; NIEBEL, E.; GRASER, H.-U.; BARTENSCHLAGER, H.; NITTER, G.; ZPLAN - PC program to optimize livestock selection programs. User's Guide for ZPLAN, Version November 1994, University Hohenheim, 1994

KOMINAKIS, A.; NITTER, G.; FEWSON, D.; ROGDAKIS, E.:

Evaluation of the efficiency of alternative selection schemes and breeding objectives of sheep in Greece. Anim. Sci. 64 (1997), 453-461

MCCLINTOCK, A.E.; CUNNINGHAM, E.P.: Selection in dual purpose cattle populations: Defining the breeding objective. Anim. Prod, 18 (1974),
$237-247$

MIESENBERGER, J.:

Zuchtzieldefinition und Indexselektion fur die osterreichische Rinderzucht. University of Agricultural Sciences, Vienna, Diss., 1997

MIESENBERGER, J.; SÖLKNER, J.; ESSL, A.;

Economic weights for fertility and reproduction traits relative to other traits and effects of including functional traits into a total merit index. Proc. Internat. Workshop on Genetic Improvement of Functional Traits in Cattle, Grub, Germany, Nov, 1997. Interbull-Bulletion 18 (1998), 78-84

MUELLER, U.:

Planungsrechnungen zur Optimierung von Zuchtsystemen zur Verbesserung der Mastleistung und Schlachtk ̋rperqualitát der Rasse Merinofleischschaf unter der Verwendung des UltraschallmeßRIEDL, M.: verfahrens am lebenden Tier. Univ. Leipzig, Doctoral Thesis, 1995

Untersuchungen zur Optimierung des Zlichtungserfolges eines konventionellen Besamungszuchtprogrammes für Milchrinder am Beispiel der sächsischen Schwarzbuntpopulation. Univ. Leipzig, Doctoral Thesis, 1996

SOLKNER, J.; MIESENBERGER, J.; WILLAM, A.; FU'RST, C.; BAUMUNG, R:

SUNDRUM, A.:

Total merit indices in dual purpose cattle. Arch. Tierz., Dummerstorf $\mathbf{A 3}(2000)$ 6, 597-608
UM, A.

Effectiveness of strategies to minimize methan release in dairy production. Abstracts of the $48^{\text {ih }}$ EAAPMeeting, 25.8 -28.8, 1997, Vienna, Austria, 1997

WÜNSCH, U; NITTER, G.; SCHUELER, L.:

Genetic and economic evaluation of genetic improvement schemes in pigs. Arch. Tierz, Dummerstorf 42 (1999) 6, 571-582

\author{
Received: 2000-02-04 \\ Accepled: 2000-11-03
}

\author{
Authors' addresses. \\ Dr. ROSWITHA BAUMUNG, Ass. Prof. Dr, JOHANN SÖLKNER, \\ Dipl Ing. ERWIN GIERZINGER, Ass. Prof. Dr. ALFONS WILLAM \\ Department of Livestock Science \\ University of Agricultural Sciences Vienna \\ Gregor-Mendel Str. 33 \\ A-II80 Vienna \\ E-Mail: Baumung@edvl.boku.ac.at
}




\section{Buchbesprechung}

\section{Tierzucht in den Tropen und Subtropen}

Band 5 des Handbuches der Landwirtschaft und Ernahrung in den Entwicklungslandern

\section{PETER HORST und INGEBORG REH (Hrsg.)}

2. vollig neu bearbeitete Auflage, 452 Seiten, 23 Farbfotos, 95 s/w Fotos, 91 Tabellen, Verlag Eugen Ulmer, Stuttgart, 1999, ISBN 3-8001-3204-4, DM 248,00; oS 1810,00; sFr 221,00

Mit diesem Buch liegt der S. und letzte Band des „Handbuch der Landwirtschaft und Ernahrung in den Entwicklungsländern" vor. In dieser vollig neu bearbeiteten und erweiterten 2. Auflage werden Stand und Perspektive der Tierzucht und -haltung in den Tropen und Subtropen im Hinblick auf die Situation der in diesen Regionen hauptsăchlich vertretenen Entwicklungslănder dargestellt. Die Herausgeber entsprechen mit diesern Buchtitel einem dringenden Bedürfnis, welches einerseits aus dem stetig steigenden Bedarf an tierischen Nahrungsmitteln und andererseits aus dem Umfang, der Regionalisierung und der Entwicklung der Haustierbestănde in diesen Lăndern resultiert. Herausgeber und das namhafte Autorenkollektiv verfïgen uber hohe wissenschaftliche Fachkompetenz mit z.T. langjahrigen Erfahrungen aus Tatigkeiten in Ländern dieser Regionen.

Anliegen dieses Buches ist die Darstellung von Gegebenheiten, Engpăssen und Potentialen der tierischen Produktion in diesen Ländern, ihrer vielfaltigen und sich gegenseitig beeinflussenden klimatischen, technischen, sozialen und wirtschaftlichen Faktoren, die auf die Zilchtung und Haltung landwirtschaflicher Nutztiere Einfluss nehmen und das ist den Autoren hervorragend gelungen. Die Besonderheit des Buches liegt, neben der Darstellung der Produktionstechnik, bei den in den Tropen und Subtropen gehaltenen Nutztierarten, in der Komplexität der lănder- und tierartenubergreifenden Information spezieller Probleme in der Tierproduktion. Dieser Vorzug wird bei der Betrachtung der jeweils am Ende jedes Kapitels angefugten umfangreichen Literaturverzeichnisse besonders deutlich. Das Buch ist ubersichtlich in tierartentubergreifende Problemdarstellungen, die Managementsituation bei den wesentlichen Nutztierarten und Fragen der Weidewirtschaft gegliedert. Beginnend mit dem Stand der Nutztierproduktion in der Welt, folgt der Hauptabschnitt zu den speziellen Problemen der Nutztierproduktion in den Tropen und Subtropen, darunter Klimafaktoren und Adaptation, Nährstoffversorgung und Futterverfugbarkeit, Tierkrankheiten und Kontrollmaßnahmen, Züchtung und die Förderung der Tierproduktion. Ein weiterer umfangreicher Hauptteil ist der Produktionstechnik bei den Nutztierarten: Rind, Búffel, Schaf, Ziege, Equiden, Kameliden, Schwein, Geflugel, Kaninchen, Meerschweinchen und Bienen gewidmet. Bei den jeweiligen Tierarten finden sich u.a. Informationen zu Leistungen, Rassen, Zuchtmaßnahmen, spezieller Produktionstechnik, Futterung, Krankheiten usw. Da in diesen Landern dic Tierhaltung uberwiegend in den Handen von Kleinbauern, Kleinhaltern und in einigen Gebieten von Nomaden und Seminomaden liegt, erhalt die kritische Betrachtung der technischen Managementpraktiken unter Berücksichtigung sozio-ökonomischer Einflussfaktoren in den uberwiegend kleinbetrieblichen Nutzungsformen ein besonderes Gewicht, Im letzten Buchteil wird die Nutzung von Wild- und Fischbestanden sowie Weiden und die Weidewirtschaft besprochen. Dieses sehr praxisrelevante Buch zeichnet sich u,a. darin aus, dass Probleme nicht nur benannt oder auf Besonderheiten bei einzelnen Themen oder Regionen hingewiesen wird, sondern dass praktikable Wege und Vorgehensweisen beschrieben und empfohlen werden.

Dieses Buch kann sicher maßgeblich dazu beitragen die Entwicklungsaktivitäten zur nachhaltigen Verbesserung der Tierbestănde und Produktionssysteme an diesen Standorten zu unterstutzen. Die große Informativităt wird durch die zahlreichen Tabellen und Abbildungen unterstutzt. Es richtet sich in erster Linie an Studierende, Tierzucht- und Agrarfachpersonen und Veterinärmediziner aber auch an in der Beratung im In- und Ausland oder in der Administration tătige Mitarbeiter. Das Buch ermöglicht einen hervorragenden, komplexen Überblick der Gegebcnheiten in der tierischen Produktion und deren Potentiale in Entwicklungsländern der Tropen und Subtropen. 